\title{
Invasive Alien Plant Species in the Northwestern \& Western Provenance of Ethiopia and Linking Its' Phonological Implication to Management and Control
}

\author{
Dereje Mosissa \\ Ethiopian Biodiversity Institute Assosa Biodiversity Center, Forest and Rangeland Biodiversity Case team
}

\begin{abstract}
Biodiversity loss caused by invasive species may soon surpass the damage done by habitat destruction and fragmentation. Biological invasions are an important component of human-caused global environmental change. Invasive alien species are now a major focus of global conservation concern. The decisions need to be made on whether benefits derived from the invasive spread of an alien species outweigh the reduced value of ecosystem services, e.g. the loss of grazing land in areas invaded with Lantana camara and Senna occidentalis. It is necessary to consider actions to deal with the current problems caused by invasive species and to reduce the magnitude of the problem in the future. The present catalogue on invasive alien plant species of the northwestern \& Western Ethiopia is therefore timely one. It focuses on some species of invasive alien plants in Ethiopia. These include the most serious invasives, such as Alternanthera philoxeroides, Cassia uniflora, Chromolaena odorata, Eichhornia crassipes, Lantana camara, Parthenium hysterophorus, Senna obtusifolia and others. I am confident that this publication will be immense value to foresters, environmentalists, field researchers and conservation managers to pay attention on the ecological impact of invasive aliens both at the species and at the ecosystem levels.
\end{abstract}

Keywords: Biodiversity, invasive species, conservation, environmental change

DOI: $10.7176 /$ ALST/74-04

Publication date:May $31^{\text {st }} 2019$

\section{Background}

"Loss of habitat constitutes the greatest threat to the existence of biodiversity The second worst threat is the biological invasion of alien species (Convention for Biological diversity, 1992)"

An alien plant species also referred to as exotic, introduced, foreign, non-indigenous or nonnative, is one that has been introduced by humans intentionally or otherwise through human agency or accidentally from one region to another. An alien plant that has escaped from its original ecosystem and is reproducing on its own in the regional flora is considered a naturalized species. Those naturalized aliens that become so successful as to spread in the flora and displace native biota or threatens valued environmental, agricultural or personal resources by the damage it causes are considered invasive.

Humans have been transporting animals and plants from one part of the world to another for thousands of years, sometimes deliberately for social or personal gain and sometimes accidentally. In most cases, such introductions are unsuccessful, but when they do become established as an invasive alien species (defined by IUCN (2000) as "an alien species which becomes established in natural or semi-natural ecosystems or habitat, is an agent of change, and threatens native biological diversity"), the consequences can be catastrophic. According to the Convention for Biological Diversity, invasive alien species are the second largest cause of biodiversity loss in the world and impose high costs to agriculture, forestry, and aquatic ecosystems. In fact, introduced species are a greater threat to native biodiversity than pollution, harvest, and disease combined.

The global extent and rapid increase in invasive species is homogenising the world's flora and fauna (Mooney \& Hobbs, 2000) and is recognized as a primary cause of global biodiversity loss. Bio-invasion may be considered as a form of biological pollution and significant component on global change and one of the major causes of species extinction (Mooney and Drake, 1987; Drake et al., 1989).

Foresters, taxonomists and ecologists are now well aware of the problems caused by the invasion of alien species into natural areas and the associated negative effects on global patterns of native biodiversity. Once established, some alien species have the ability to displace or replace native plant and animal species, disrupt nutrient and fire cycles, and cause changes in the pattern of plant succession. Studies are underway to better understand the impacts of these species on native ecosystems.

Many invasive plants continue to be admired by people who may not be aware of their weedy nature. Others are recognized as weeds but property owners fail to do their part in preventing their spread. Some species do not even become invasive until they are neglected for a long time. Invasive plants are not all equally invasive. Some only colonize small areas and do not do so aggressively. Others may spread and come to dominate large areas in just a few years. The loss due to invasive species in United States estimated to be $\$ 125-150$ billion each year and 25\% of US agriculture gross national product lost due to foreign pests and weeds (McNeely et al. 2001). 
Alien plants can spread rapidly because of our mobile society and the intentional transportation of ornamental and forage plants (Randall and Marinelli, 1997).

\subsection{Characteristic features of Invasive species:}

Invasive species possess characteristic features like "pioneer species" in varied landscapes, tolerant of a wide range of soil and weather conditions, generalist in distribution, produces copious amounts of seed that disperse easily, grows aggressive root systems, short generation time, high dispersal rates, long flowering and fruiting periods, broad native range, abundant in native range. Preliminary data from one interesting study shows that invasive species are likely to have relatively small amounts of DNA in their cell nuclei. Apparently, the cells in these plants are able to divide and multiply more quickly and consequently the entire plant can grow more rapidly than species with higher cellular DNA content. This gives them a leg up in disturbed sites.

\subsection{Global trade and Species introductions: intentions and accidents}

The trade-based global economy stimulates the cultivation of economically important species. But it also stimulates the accidental spread of same species or others. International law regulating the unintentional introduction of harmful alien species through trade is weak. There are two major conventions with provisions on aliens. One is the International Plant Protection Convention (IPPC), which presently addresses crop pests only. The IPPC could be expanded in scope to explicitly protect native (nonagricultural) plant life from introduced pests. The other major international agreement addressing alien species, the Convention on Biological Diversity, lacks teeth (Jenkins, 1999). Article 8(h) addresses alien species by calling for the parties to: "as far as possible and as appropriate: ... Prevent the introduction of, control or eradicate those alien species which threaten ecosystems, habitats or species".

\subsection{Monitoring:}

Monitoring is required in the invasive species management to determine: location/early detection of problematic species, whether a species is likely to become a problem in an area, whether a species is responding to management efforts (if taken?), the impact of alien plant control methods on native species. Monitoring of Invasion can be done through qualitative approach like species inventory (seasonally) and quantitative approach using phytosociological methods and mapping using ground-based methods (via map overlays or GPS), remotely-sensed images (aerial photos, high resolution multispectral digital data).

\subsection{Control:}

Current control methods for invasive aliens are expensive, lengthy, and risky because total eradication is required to prevent reestablishment. Effective site-eradication procedures require multi-year treatments, continued monitoring, and follow-up treatments. All infestations on adjacent lands must be treated to prevent reinvasion. Unfortunately, infestations common along railway tracks, roads, and utility right-of-ways are rarely treated for eradication, fostering widespread immigration to adjacent lands. Common methods for control of invasive weed species are: Mechanical, Chemical and Biological control.

Mechanical Control: It is one of the common methods employed for control of invasive species. Mechanical control involves ploughs, scythes, mowers, hoes, cultivators, rotary weeders etc. Using these tools, the weeds are physically lifted from the soil, cut off or buried. But it is laborious and needs lot of man power.

Chemical Control: This method has proved costly and partly successful in several cases.

Using of chemicals is not desirable due to pollution that they cause.

Biological Control: In most cases of alien pest invasions, biological control has proven the most effective and environmentally sound approach to their management. Introducing a natural enemy (e.g. water hyacinth weevil Neochetina spp. for Eicchornia; Lantanophaga pussilidactyla insect for Lantana camara, Zygogramma bicolorata insect and Cassia uniflora plant species for Parthenium hysterophorus) for eradication of invasive species is a current focus of interest for biological conservationists. But biological control may not be evenly effective over all areas infested by the invasive species.

Past research studies for developing eradication methods were often limited in duration (only one or two years) and habitats (one site). Appropriate long-term support and funding has been lacking. Control projects for invasive species, offer a logical, long-term solution but none have been seriously attempted in India. The high investments and longterm research required for control programs have been made only for western rangeland alien plant species, and more recently for tropical aliens in Florida.

Crucial aspects of alien plant ecology that influence control strategies are as follows:

1. Invasive aliens continue to spread because natural predators were not imported from the plant's home range and native predators are too weak;

2. After an alien plant is introduced there is a "lag phase" of decades to centuries before an exponential spread phase (Baskin 2002). Thus, some species that currently appear non-invasive may eventually begin to spread 
rapidly.

3. Invasive alien plants can prevent or retard natural succession and reforestation by forming dense infestations.

4. Invasion by aliens continues to decrease biological diversity and detract from their primary mission;

5. The partial shade tolerance of some alien species (Cassia pumila) allows them to become established under developed forest canopies;

6. Alternanthera philoxeroides, Eicchornia crassipes and Pistia stratiotes are invading riparian/aquatic habitats to the exclusion of native species and regeneration;

7. The initial spread of aliens were observed along highway and utility right-ofways, "disturbed habitats," and riparian systems, greatly facilitates migration into extensive forest areas; and

8. Because many "disturbed habitats" occur in cities, alien plants can present severe problems for urban forestry programs, which is made more difficult by alien species mixtures.

9. Allelopathic effect by species like Prosopis juliflora, Hyptis suaveolens, Lantana camara retard the growth of other species.

10. The invasions potentially lead to an increase in species richness, as invasive species are added to the existing species pool. But also leads to extinction of native species, resulting in decrease of species richness. The negative interactions is primarily the competition with natives for food and sustenance, which may not allow coexistence.

\subsection{Research Issues, Legal and Institutional Needs:}

There is no question that understanding and dealing with the invasive problem is an enormous challenge. To meet this need SCOPE (Scientific Committee on Problems of Environment) is calling for a focused, coordinated, and broadly based approach to the invasive species problem that would engage the large, and global concerned with these issues. It is recognized that research initiatives in India are now needed to improve the understanding of the ecology of the invasive process, the knowledge on predictive powers on which species are likely to become invasive and under what conditions, characteristics of invasive species, impacts of global climate change on invasive species.

It is realized that a legal and institutional approach to the country's biosecurity threat is a prerequisite to long-term success against introduction of invasive species. The government should strengthen its quarantine authority through new legislations which prohibits the introduction of alien species without an approved consent or permit. Also unauthorized introduction of wild and domesticated animals and plants into new areas, between states and within the country should be reviewed and monitored by several government departments, viz. Forest, Agriculture, Environment, Veterinary and Public Health.

We need to develop techniques to make rapid assessment of the status and movement of invaders and of their potential ecosystem impacts. At present our knowledge about the status of invaders is generally of two states only - it is present (which is derived from flora lists) or it is firmly established and doing devastating damage (often learned from the popular newspapers). Information is needed between these two extremes. In order to acquire this information a rapid sapling approach is needed that would produce a quantitative assessment of the status of invading species, that could be repeated at intervals, to provide a clear focus on emerging problems, helping to alleviate the crisis management approach to invaders. Efforts are needed to utilize developing technologies for tracking invasives including remote sensing and GIS. Further, we need to develop global maps of the distributions of the most abundant and most devastating invasive species, as well as the most sensitive ecosystem types (Mooney, 1999).

\section{Ethiopia (study area)}

Ethiopia is located in the horn of Africa between $3^{\circ}$ and $18^{\circ}$ North latitude, $33^{\circ}$ and $48^{\circ}$ east longitude, and lies within the tropics. It has diverse Physiogeographic features with high and rugged mountains, flat topped plateau, deep gorges, incised river valleys and rolling plains. The altitudinal variation ranges from $110 \mathrm{~m}$ below sea level in same areas of Kobar Sink, to 4,620 meters above sea level (masl) at Ras Dashen. The Great Rift Valley runs from northeast to southwest of the country and separates the western and southeastern highlands. The high lands on each side of the rift valley give way to extensive semi-arid lowlands to the east, south and west of the country. 


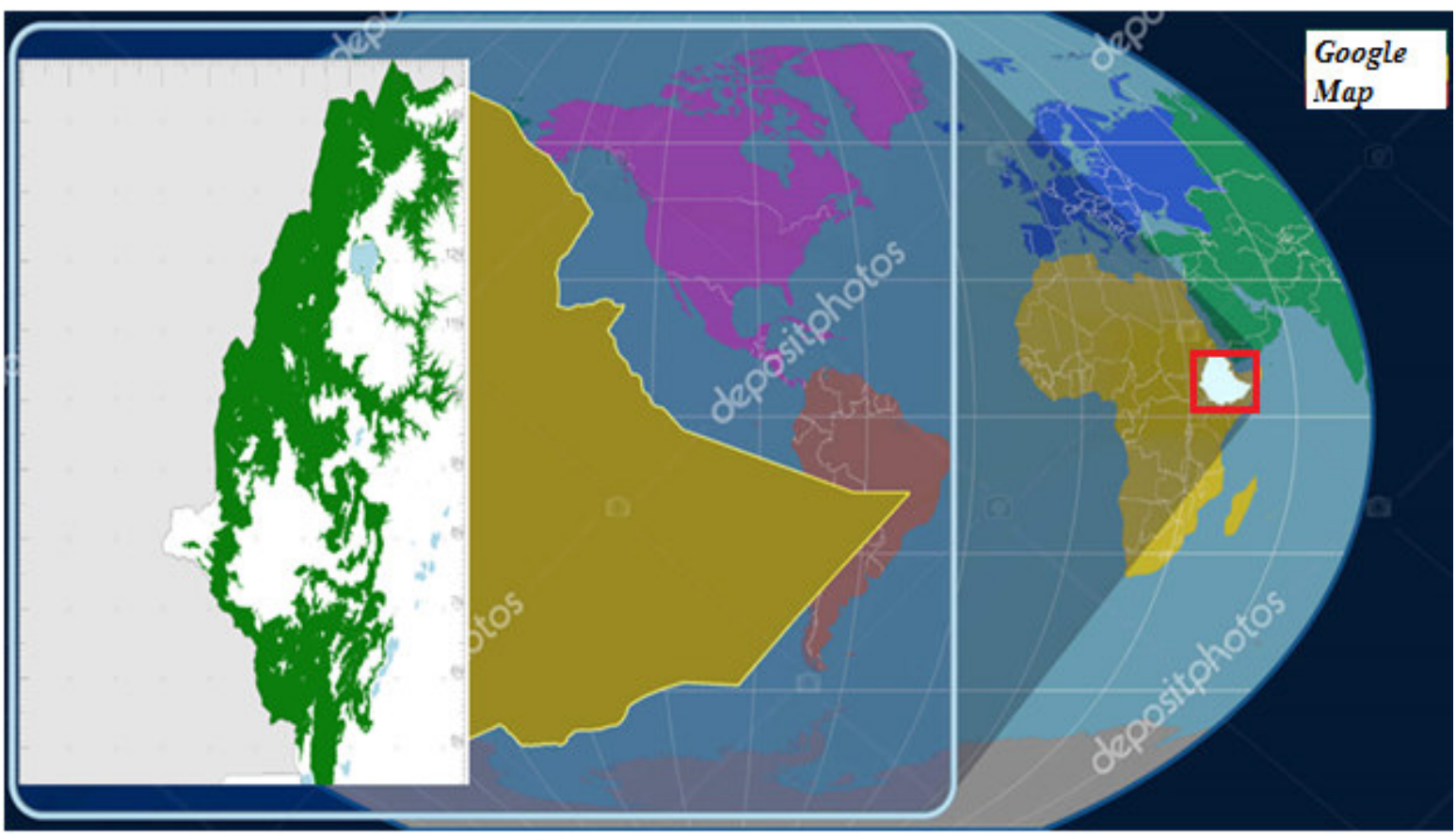

Figure 1: Map of Ethiopia (the Northwestern provenance)

Ethiopia is a tropical country with varied macro and micro-climatic conditions that have contributed to the formation of diverse ecosystems inhabited with a great diversity of life forms of both animals and plants. The rain fall distribution is seasonal and is mainly governed by the inter annual oscillation of the surface position of the Inter-Tropical Convergence Zone (ITCZ), that passes over Ethiopia twice a year. This causes variations in the wind flow patterns and the onset and withdrawal of winds from north and south. The mean annual rainfall patterns range from $500 \mathrm{~mm}$ to $2,800 \mathrm{~mm}$. The South western region receives the heaviest annual rainfall which goes up to $2,800 \mathrm{~mm}$ in some areas. The central and northern central regions receive moderate rainfall that declines towards northeast and eastern Ethiopia, and the southeastern and northern regions receive an annual rainfall of about $700 \mathrm{~mm}$ and $500 \mathrm{~mm}$. respectively. The relative humidity regimes that closely follow the rainfall pattern, the rainfall pattern itself and the high variation in temperature $(>300 \mathrm{C}$ and $<100 \mathrm{C})$ influence types and diversity of the vegetation and their distribution over the country (Leipzig,1996).

Flora:

According to World Conservation Monitoring Centre (WCMC), 1,604,000 species have been described at the global level. Thus Ethiopia accounts for $4.4 \%$ of the global biodiversity existing in only $2.4 \%$ land area of the world. According to Tesfaye Awas (2007) the number of flowering plant species endemic to the present political boundaries of this country is 840 out of a total of 7000, i.e. $12 \%$. (Tesfaye Awas 2007). Ethiopia is an important center of agri-biodiversity having contributed 167 species to the world agriculture and homeland for 320 species of wild relatives of crops. Ethiopia's rich vegetation wealth and diversity is undoubtedly due to the immense variety of the climatic and altitudinal variations coupled with varied ecological habitats.

\section{A. Introduced plants from Australia:}

Acacia dealbata, Acacia decurrens, Acacia holosericea, Acacia longifolia, Acacia mangium, Acacia melanoxylon, Araucaria bidwilli, Arancaria columnaris, Araucaria cunnighamii, Araucaria excelsa, Brassaia actinophylla, Callistemon lanceolatus, Callitris cupressiformis, Callitris glauca, Castenospermum australe, Casuarina equisetifolia, Eucalyptus alba, Eucalyptus camaldulensis, Eucalyptus citriodora, Eucalyptus globulus, Eucalyptus grandis, Eucalyptus paniculata, Eucalyptus punctata, Eucalyptus saligna, Eucalyptus tereticornis, Eucalyptus torelliana, Eucalyptus viminalis, Grevillea banksii, Grevillea robusta, Melaleuca leucodendron, Stenocarpus sinuatus, Thuja occidentalis, Thuja orientalis.

\section{B. Introduced species from Western Asia and Europe:}

Allium cepa, Allium sativum, Althaea rosea, Asparagus officinalis, Avena sativa, Brassica oleracea, Cicer arietinum, Coriandrum sativum, Ficus carica, Lactuca sativa, Lens culinaris, Medicago sativa, Morus nigra, Nerium oleander, Papaver somniferum, Pisum sativum, Spinacea oleracea.

\section{Introduced species from the Mediterranean Area and Africa:}

Aloe variegata, Antirrhinum majus, Asparagus plumosus, Avena fatua, Briza maxima, Calendula bicolor, Capsella bursa-pastoris, Carthamus tinctorius, Cassia didymobotrya, Catharanthus roseus, Chenopodium album, Chenopodium murale, Chrysanthemum coronarium, Cichorium endivia ssp. divaricatum, Convolvulus arvensis, Cyperus flabelliformis, Foeniculum vulgare, Haworthia coarctata, Hordeum vulgare, Ipomoea batatas, 
Ipomoea cairica, Lathyrus sativus, Nasturtium officinale, Nerium indicum, Nigella damascena, Oxalis purpurea, Pelargonium inquinans $x$ zonale, Pelargonium $x$ hybridum, Pennisetum typhoides, Plantago major, Poa annua, Raphanus sativus, Ricinus communis, Salvia officinalis, Sansevieria trifasciata, Senecio vulgaris, Sisymbrium officinale, Spergula arvensis, Stellaria media, Taraxacum officinale, Verbena officinalis, Verbena supina, Veronica arvensis, Vicia benghalensis.

\section{B. Introduced species from Europe/ America/Mexico/West Indies/Brazil}

Agave americana, Agave sisalana, Allamanda cathartica, Allamanda violacea, Anacardium occidentale, Arundo donax, Angelonia biflora, Annona muricata, Annona reticulata, Annona squamosa, Arachis hypogaea, Asclepias physocarpa, Averrhoa bilimbi, Averrhoa carambola, Bauhinia blakeana, Begonia manicata, Beta vulgaris, Bignonia alliacea, Bignonia megapotamica, Bixa orellana, Bixa orellana, Bougainvillea glabra, Bougainvillea spectabilis, Brassica rapa, Browallia viscosa, Brunfelsia americana, Caesalpinia coriaria, Caesalpinia pulcherrima, Caladium bicolor, Capsicum annuum, Capsicum frutescens, Carica papaya, Cassia grandis, Catesbaea spinosa, Ceiba pentandra, Centaurea cyanus, Cereus caesius, Cestrum diurnum, Cestrum nocturnum, Chenopodium ambrosioides, Chorisia speciosa, Citharexylum subserratum, Cleome spinosa, Clitoria ternatea, Cocos nucifera, Colvillea racemosa, Conyza bonariensis, Coreopsis lanceolata, Coreopsis stillmanii, Coriandrum sativum, Cosmos bipinnatus, Couroupita guianensis, Crescentia cujete, Cuphea lanceolata, Dahlia variabilis, Datura stramonium, Daucus carota, Delonix regia, Delphinium ajacis, Dianthera secunda,

Dianthus barbatus, Dieffenbachia seguine, Duranta repens, Eruca sativa, Eschscholtzia californica, Euphorbia pulcherrima, Fragaria vesca, Furcraea foetida, Gaillardia pulchella, Godetia amoena, Gossypium herbaceum, Gossypium hirsutum, Graptophyllum pictum, Guazuma tomentosa, Gustavia augusta, Hamelia patens, Helianthus annuus, Hibiscus elatus, Hibiscus liliiflorus, Hibiscus sabdariffa, Iberis amara, Ipomoea indica, Iresine herbstii, Jacaranda mimosaefolia, Jacquemontia pentantha, Jacquinia ruscifolia, Jatropha panduraefolia, Jatropha multifida, Kigelia pinnata, Lathyrus aphaca, Lychnis coeli-rosa, Lycopersicon esculentum, Magnolia grandiflora, Malpighia coccigera, Malpighia glabra, Malva parviflora, Malvaviscus arboreus, Manihot esculenta, Manilkara achras, Medicago lupulina, Medicago polymorpha, Mentha piperita, Millettia peguensis, Monstera deliciosa, Morus nigra, Musa acuminata, Nicotiana alata, Nicotiana tabacum, Ochroma pyramidale, Oenothera rosea, Opuntia elatior, Opuntia imbricata, Opuntia microdasys, Opuntia vulgaris, Oxalis latifolia, Papaver rhoeas, Parkinsonia aculeata, Passiflora edulis, Passiflora suberosa, Pavonia hastata, Persea americana, Petrea volubilis, Petunia axillaris, Phoenix dactylifera, Physalis peruviana, Pinus caribaea, Pinus gregii, Pinus merkusii, Pinus michoacana, Pinus occidentalis, Pinus oocarpa, Pinus patula, Pinus pringlei, Pinus pseudostrobus, Pinus rudis, Pinus taiwanensis, Pisonia grandis, Pithecellobium dulce, Plumeria alba, Plumeria rubra, Portlandia grandiflora, Portulaca grandiflora, Portulacaria afra, Prunus domestica, Psidium guajava, Punica granatum, Pyrostegia venusta, Rauvolfia tetraphylla, Ravenia spectabilis, Reseda odorata, Rhoeo discolor, Rivina humilis, Russelia equisetiformis, Salvia splendens, Solanum grandiflorum, Solanum tuberosum, Solidago canadensis, Spergula arvensis, Stellaria media, Stigmaphyllon ciliatum, Tabebuia chrysantha, Tabebuia pentaphylla, Tabebuia rosea, Tagetes erecta, Talinum calycinum, Tamarindus indica, Tecoma gaudichaudii, Tecoma stans, Tecomaria capensis, Tecomella undulata, Theobroma cacao, Thevetia peruviana, Thunbergia alata, Thunbergia erecta, Thyrallis glauca, Tithonia rotundifolia, Tropaeolum majus, Vaccaria pyramidata, Verbena peruviana, Vernonia elaeagnifolia, Vicia hirsuta, Viola odorata, Viola tricolor, Yucca gloriosa, Zebrina pendula, Zea mays, Zephyranthes grandiflora, Zinnia elegans. In Ethiopia, comprehensive studies on invasive species and plant invasions are still missing. In view of this, the present study attempted to focus on the invasive alien species in the flora of Ethiopia and Eritrea.

\section{Methodology}

The present study was conducted during 2017 - 2019, to compile a comprehensive list of invasive alien plant species. The challenge is recognizing which introduced species incur ecological and economic costs and which simply becomes part of Ethiopia's tropical/subtropical/temperate landscape and cause no real harm. It is very difficult to choose alien species, from all over the country, that really are "invasive" or "worse" than any others. After an extensive review of literature on global invasive species (Mooney and Drake, 1987; Heywood, 1989; Cox, 1999; Cox, 2004; Cracraft and Grifo 1999; D'Antonio and Vitousek, 1992; Drake et al. 1989; Randall et al. 1997; Huxel, 1999; Jenkins, 1999; Londsdale, 1999; Mooney, 1999; Elton, 2000; Mooney and Hobbs, 2000; Almeilla and Freitas, 2001; Cowie, 2001; McNeely et al. 2001) and of Ethiopia and their spread based on history, species origin, species behavior and field observations, a list of 60 species of invasive aliens was prepared. The websites were also examined extensively for background information. Of these, some species may have invaded only a restricted region, but have a huge probability of expanding and causing great damage. Some species are ready colonizers in disturbed areas and may have less impact on natural populations. Other species may already be globally widespread and causing cumulative but less visible damage.

The nativity of the species is provided based on Matthew, 1969; Maheswari and Paul, 1975; Nayar, 1977; Sharma, 1984; Hajra and Das, 1982; Saxena, 1991; Pandey andParmar, 1994; Reddy et al. 2000; Reddy \& Raju, 
2002; Reddy \& Reddy, 2004; Murthy et al. 2007; Negi and Hajra, 2007.

\section{Results and Discussion}

Total 60 species in 47 genera and under 23 families were documented as Invasive alien plant species, representing $1 \%$ of the Ethiopian flora. The 60 invasive alien species were shown along with family name, habit and nativity in table 1 . Tropical America (with 128 species) region contribute the greatest to the number (74\%) followed by tropical Africa (11\%). The other regions, which contribute minority, are Afghanistan, Australia, Brazil, East Indies, Europe, Madagascar, Mascarene Islands, Mediterranean, Mexico, Peru, Temperate South America, Trop. West Asia, West Indies and Western Europe.

Habit wise analysis shows that herbs with 151 species (87.3\%) predominate followed by shrubs (14), climbers (5) and trees (3). Of the 23 families, Asteraceae is the most dominant family with 13 species followed by Papilionaceae (8), Euphorbiaceae (6), Caesalpiniaceae (4) and Convolvulaceae (3). The top ten families contribute 110 species with proportion of $63.6 \%$. The 17 families represent one species each, i.e. Solanaceae, Amaranthaceae, Poaceae, Apocynaceae, Araceae, Arecaceae, Balsaminaceae, Cactaceae, Liliaceae, Melastomataceae, Nyctaginaceae, Oxalidaceae, Papaveraceae, Passifloraceae, Piperaceae, Polygonaceae, Rubiaceae, Salviniaceae, Typhaceae and Urticaceae.

While a number of lists of invasive plant species are in worldwide circulation, criteria used in these listings often are not documented clearly. Surveys have shown that more than half of alien plant species currently spreading naturally were intentionally introduced, and that most of the alien species that endanger India's native ecosystems were first introduced for horticultural purposes. Thus reducing the intentional use of high-risk alien plants could reduce the spread and impact of invasive plants in the country.

All these species reported here, were reported as "weeds" in other countries or invasive alien plants in most of the regions. Almost $80 \%$ of the Invasive alien plant species were introduced from Neotropics. The invasive alien species are ready colonizers in disturbed areas and cause considerable ecological damage to India's natural areas, speed the disappearance of threatened and endemic species, reduce the carrying capacity of pastures, increase the maintenance costs of croplands, and interfere with our enjoyment of the outdoors. Of these, some species may have invaded only a restricted region, but have a huge probability of expanding, and causing great damage. Other species may already be globally widespread and causing cumulative but less visible damage.

Among the 60 species, majority are generalists found in all kinds of systems like forests, crop lands, waste lands, plantations, gardens and road sides. The 33 species are invaders of wetlands, i.e. Aerva javanica, Aeschynomene americana, Alternanthera paronychioides, Alternanthera philoxeroides, Asclepias curassavica, Cassia alata, Corchorus trilocularis, Cyperus difformis, Cyperus iria, Echinochloa colona, Echinochloa crusgalli, Eclipta prostrata, Eichhornia crassipes, Fuirena ciliaris, Gnaphalium coarctatum, Gnaphalium pensylvanicum, Gnaphalium polycaulon, Grangea maderaspatana, Ipomoea carnea, Ludwigia adscendens, Ludwigia octovalvis, Ludwigia perennis, Mecardonia procumbens, Monochoria vaginalis, Pistia stratiotes, Portulaca quadrifida, Rorippa dubia, Saccharum spontaneum, Salvinia molesta, Sesbania bispinosa, Sonchus asper, Sonchus oleraceus and Typha angustata.

The predominance of Asteraceae species in invasive category shows the high impact of neotropical flora on Indian region. In addition to negative impact on indigenous flora and economy, some alien plants were very much useful to local people. A prominent examples are Prosopis juliflora, Borassus flabellifer and Leucaena leucocephala. Among the reasons for the admiration expressed for these plants are: adaptability, rapid growth and multiple uses. Prosopis juliflora used for coal extraction, firewood, erosion control, fencing. Borassus flabellifer is an economically important species, introduced to India in ancient times. The cut flower stalks yield sugar and toddy, the fruits are roasted and eaten, leaves are used for thatching. Leucaena leucocephala used for firewood, erosion control, fodder, green manures, providing shade and shelter for other crops. Several alien weedy plants like Argemone mexicana, Cassia tora, Cleome viscosa, Chamaesyce hirta, Croton bonplandianum, Eclipta prostrata, Ipomoea carnea, Malachra capitata, Mimosa pudica, Physalis angulata, Tridax procumbens were used in native medicine. Alternanthera philoxeroides and Portulaca oleracea were used as leafy vegetables.

\subsection{Description of some of biologically important Invasive Alien Plant species Ageratum conyzoides Family: Asteraceae \\ Pop. Name: Goat weed \\ Nativity: Trop. America \\ Distribution in Ethiopia: Throughout \\ Propagation: Seeds \\ $\boldsymbol{F l} \& \boldsymbol{F r}$ : July - January \\ Citation: Ageratum conyzoides L. Sp. Pl. 938. 1753; FBI 3: 243. 1881; Gamble 2: 672 (476).1921.}

Description: Annual, erect, foetid herbs up to $1 \mathrm{~m}$ tall. Leaves ovate to triangular, 3-8 x 1-3.5 cm, base rounded or truncate, margin serrate, apex acute or acuminate. Heads in terminal corymbs. Florets blue or white. Achenes 
black, 5-angled. Pappus scales 5, serrate, awn-tipped.

Remarks: Aggressive colonizer. Troublesome weed in gardens, cultivated fields and forests.

Alternanthera pungens

Family: Amaranthaceae

Nativity: Trop. America

Distribution in the region: Primarily recorded from Sherkole, Mengie \& Kurmuk Districts of BGRS, Northwest of Ethiopa

Propagation: Seeds, Vegetative

$\boldsymbol{F l} \& \boldsymbol{F r}$ : August - December.

Citation: Alternanthera pungens Kunth in H.B.\& K. Nov. Gen. Sp. 2: 206. 1817. Achyranthes repens L.Sp. Fl. 205. 1753.

Description: Spiny, prostrate herb to $50 \mathrm{~cm}$; branches vilous-hairy. Leaves of the same pair unequal, obliquely elliptic to suborbicular, opposite-decussate, $1.5-3 \times 1-2 \mathrm{~cm}$, attenuate to cuneate, apex obtusely apiculate; spikes 2 or more, $0.5-1.5 \times 0.5-1 \mathrm{~cm}$, in axillary clusters, seeds discoid, $1 \mathrm{~mm}$ across.

Remarks: Troublesome weed in gardens, cultivated fields and forest openings.

Argemone mexicana

Family: Papaveraceae

Pop. Name: Prickly Poppy

Nativity: Trop. Central \& South America

Distribution in Ethiopia: Throughout

Propagation: Seeds

$\boldsymbol{F l} \boldsymbol{\&} \boldsymbol{F r}:$ September - January

Citation: Argemone mexicana L. Sp. Pl. 508. 1753; FBI 1:117. 1872; Dunn in Gamble 1:32 (25).1915.

Description: Annual prickly herbs. Latex yellow. Leaves glaucous, prickly, sinuate, pinnatifid. Flower bright yellow, solitary, terminal; stigmas red. Capsules erect, prickly, oblong, porocidal; seeds numerous, black, used to adulterate mustard seed.

Remarks: Aggressive colonizer. Common winter season weed in cultivated fields, scrub lands and fringes of forests.

Blumea obliqua

Family: Asteraceae

Nativity: Trop. America

Distribution in Ethiopia: Throughout

Propagation: Seeds

$\boldsymbol{F l} \& \boldsymbol{F r}$ : August - January

Citation: Blumea obliqua (L.) Druce in Rep. Bot. Soc. Exch. Club. Brit. Isles 4: 609. 1917. Erigeron obliqum L. Mant. P1. 573. 1771. B. amplectans DC. in Wight Contrib. Bot. Ind. 13: 1834; FBI 3: 260. 1881; Gamble 2: 681(482).1921.

Description: Annual erect or decumbent, woody, deep-rooted, villous, annual herb to $75 \mathrm{~cm}$ tall. Leaves sessile, base sub amplexicaul, spiral, oblong or obovate; lower dentate, the upper often entire, alternate. Heads terminal, disciform, solitary or two, heterogamous. Ray florets pink. Disc florets yellowish. Achenes oblong, hairy, pappus creamy.

Remarks: Aggressive colonizer. Common weed of cultivated fields, grasslands, forests, scrub and waste lands.

Calotropis procera

Family: Asclepiadaceae

Pop. Name: Madar, Swallow Wort

Nativity: Trop. Africa

Distribution in Ethiopia: Throughout

Propagation: Seeds

$\boldsymbol{F l} \boldsymbol{\&} \boldsymbol{F r}:$ March - December

Citation: Calotropis procera (Ait.) R.Br. in Ait. Hort. Kew. ed. 2. 2: 78.1811; FBI 4:18.1883; Gamble 2: 832(585).1923. Asclepias procera Ait. Hort. Kew. ed. 1.1:305.1785.

Description: Large bushy shrubs to $2 \mathrm{~m}$ tall. Leaves decussate, obovate, 6-13 $\times 3-9 \mathrm{~cm}$, coriaceous, base auriculate, apex acute, subsessile. Inflorescence an axillary or terminal umbellate panicle. Corolla white or purple, lobes erect. Follicles subglobose or ovoid, to $7.5 \mathrm{~cm}$ long. Seeds light brown, minutely tomentose.

Remarks: Aggressive colonizer. Occasional in cultivated fields, waste lands, scrub lands.

Chamaesyce hirta

Family: Euphorbiaceae

Pop. Name: Snake weed

Nativity: Trop. America 
Distribution in Ethiopia: Throughout

Propagation: Seeds

Fl \& Fr: August - December

Citation: Chamaesyce hirta (L.) Millsp. in Field Columb. Mus. Bot. ser. Publ. 2: 303. 1909. Euphorbia hirta L. Sp. P1. 454. 1753; Gamble 2: 1275 (892). 1925. E. pilulifera non L.: FBI 5: 250. 1887.

Description: Erect or decumbent herbs to $50 \mathrm{~cm}$ tall. Leaves $0.5-3 \times 0.6-1.6 \mathrm{~cm}$, elliptic-lanceolate, obliquely acute-rounded at base, margin serrulate-serrate, apex subacute-acute, chartaceous. Flowers greenish, in axillary, cymose cyathia. Capsule $1.8 \mathrm{~mm}$, pubescent. Seeds $1 \mathrm{~mm}$, angled, shallowly furrowed.

Remarks: Aggressive colonizer. Abundant along railway tracks, road sides, in cultivated fields and forests.

Crassocephalum crepidioides

Family: Asteraceae

Nativity: Trop. America

Distribution in Ethiopia: Throughout

Propagation: Seeds

$\boldsymbol{F l} \& \boldsymbol{F r}$ : July - December

Citation: Crassocephalum crepidioides (Benth.) Moore in J. Bot. 50: 211. 1912. Gynura crepidioides Benth. in Hook.f. Fl. Niger 438. 1849.

Description: Annual, erect herbs to $1 \mathrm{~m}$ tall. Stem striated. Leaves elliptic-ovate, 4-12 x 2-5 cm, base cuneateattenuate, margin dentate, apex acuminate. Heads in terminal corymbs, brick red or yellow-red, homogamous; style branches triangular at apex. Achenes oblong, ribbed.

Remarks: Occasional weed among open canopies of moist deciduous and evergreen forests.

Crotalaria pallida

Family: Papilionaceae

Nativity: Trop. America

Distribution in Ethiopia: Throughout

Propagation: Seeds

Fl \& Fr: August - March

Citation: Crotalaria pallida Dryand in Ait Hort. Kew. Ed. 1.3:20.1789. C. striata DC. Prodr. 2. 131. 1925; FBI 2: 84. 1876. Gamble 1:302 (212). 1918. C. striata DC. var. acutifolia Trimen, Handb. Fl. Ceylon 2:10. 1894;Gamble 1: 301 (213). 1918.

Description: Undershrubs to $1.5 \mathrm{~m}$ tall, branches glabrescent. Leaves 3-foliolate, leaflets elliptic or obovate, 3-6 x 2-4 cm, chartaceous, punctate, base cuneate to subacute, entire, apex obtuse, mucronate. Flowers yellow in terminal or lateral, elongated racemes, many-flowered. Pod oblong, terete, much exceeding calyx. Seeds up to 50. Remarks: Aggressive colonizer. Common along railway tracks, road sides and in degraded forests.

Crotalaria retusa

Family: Papilionaceae

Nativity: Trop. America

Distribution in Ethiopia: Throughout

Propagation: Seeds

Fl \& Fr: August - February

Citation: Crotalaria retusa L. Sp. P1. 715. 1753; FBI 2: 75. 1876; Gamble 1: 293(207). 1918.

Description: Undershrub; branches pubescent. Leaves simple, oblanceolate. 3-5 x 1-2 cm, chartaceous, glabrous above, pubescent below, base attenuate, margin entire, apex obtuse, retuse; Racemes terminal to $20 \mathrm{~cm}$. Corolla Slightly exceeding calyx, yellow. Pod oblong-terete, 4-4.5 x 1-1.5 cm, glabrous, much exceeding calyx. Seeds ca. 5.

Remarks: Occasional weed of open and degraded forests.

Cuscuta chinensis

Family: Cuscutaceae

Pop. Name: China Dodder

Nativity: Mediterranean

Distribution in Ethiopia: Throughout

Propagation: Seeds

$\boldsymbol{F l} \boldsymbol{\&} \boldsymbol{F r}$ : August - December

Citation: Cuscuta chinensis Lam. Encycl. Mer. 2:229.1786. var. chinensis; FBI 4: 226.1883; Gamble 2: 931(654). 1923.

Description: A leafless twining parasitic herb with filiform, much branched, glabrous, yellow to yellowish brown stems, often forming a tangled mass. Flowers white, solitary or in shortly, stalked cymes; calyx divided rather less than half way down; scales at the base of filaments, fimbriate; styles 2, distinct, elongate, slender; stigmas capitate. Capsules globose, hyaline; seeds 4 , very minutely rugose. 
Cuscuta reflexa

Family: Cuscutaceae

Pop. Name: Dodder, Sky Creeper

Nativity: Mediterranean

Distribution in Ethiopia: Throughout

Propagation: Seeds

$\boldsymbol{F l} \& \boldsymbol{F r}$ : August - December

Citation: Cuscuta reflexa Roxb. Pl. Cor. 21: 3.5.104. 1798. FBI 4: 225.1883; Gamble 2: 931 (654). 1923.

Description: A twining, leafless, parasitic herb. Branches fleshy, forming dense, yellow masses on shrubs and trees. Flowers pale white, solitary, clustered of 2-4 or in short racemes; calyx divided almost to the base; corolla lobes reflexed; scales almost at the base of corolla tube; style 1, stout; stigmas 2, distinct, fleshy, diverging. Capsules depressed globose, circumscissile near the base; seeds 2-4, black, glabrous.

Remarks: Aggressive colonizer. Occasional stem parasite on garden shrubs, trees and over hedges in scrub lands. Eichhornia crassipes

Family: Pontederiaceae

Pop. Name: Water Hyacinth

Nativity: Trop. America

Distribution in Ethiopia: Oromiya, Amhara \& SNNP regions of Ethiopia

Propagation: Vegetative

$\boldsymbol{F l} \boldsymbol{\&} \boldsymbol{F r}$ : August - December

Citation: Eichhornia crassipes (C. Martius) Solms-Loub. in A.DC. Monogr. Phan. 4: 527. 1883; Fischer in Gamble 3: 1530(1069). 1928. Pontederia crassipes C. Martius, Nov.Gen. Sp. Pl. 9.t. 4. 1823.

Description: Herb; free floating or rooted, stolons slender, roots elongate, fibrous. Leaves broadly ovaterhomboid, 5-10 cm long, as long as broad, thin-coriaceous, glabrous, base cuneate to rofund, entire, apex obtuse. Petiole elongate, spongy, with a bulbous portion about the middle. Spike terminal to $20 \mathrm{x} 5 \mathrm{~cm}$, ca. 15 -flowered. Perianth tube greenish; lobes upper one lilac, with a blue to violet bordered, yellow medium blotch.

Remarks: Aggressive colonizer. Abundant in still or slow floating waters. Nuisance for aquatic ecosystems.

Hyptis suaveolens

Family: Lamiaceae

Pop. Name: Wild Spikenard

Nativity: Trop. America

Distribution in Ethiopia: Northwestern lowland areas of Ethiopia

Propagation: Seeds

Fl \& Fr: August - March

Citation: Hyptis suaveolens (L.) Poit. Ann. Mus. Natl. Hist. Nat. 7: 472 t. 29 f.2.1806; FBI 4: 630.1885; Gamble 2:1129(789)1924. Ballota suaveolens L. Syst. Nat. ed.10. 1100. 1759.

Description: Aromatic, erect, undershrubs to $3 \mathrm{~m}$ tall; branches terete to 4-gonous, ovate, 2-7 $\mathrm{x} \mathrm{1-6} \mathrm{cm}$, chartaceous, strigose, base obliquely truncate to acute, irregularly serrulate, apex acute. Flowers in verticils or in short, stalked cymes, about 6-flowered, axillary; corolla blue. Nutlets 2, ovoid or oblong, 2 aborted and seen as rudimentary white structures at base, erect, basilar.

Remarks: Aggressive colonizer. Common weed of forests, cultivated fields and along railway tracks and road sides.

Ipomoea carnea

Family: Convolvulaceae

Nativity: Trop. America

Distribution in Ethiopia: Throughout

Propagation: Seeds

$\boldsymbol{F l} \boldsymbol{\&} \boldsymbol{F r}$ : Throughout the year

Citation: Ipomoea carnea Jacq. Enum. Syst. P1. 13:1760; Gamble 2: 919(645). 1923. ssp. Fistulosa (Choisy) D. Austin in Taxon 26: 237.1977. I. fistulosa Mart. ex Choisy in DC. Prodr. 9: 349.1845.

Description: Large erect shrubs to $3 \mathrm{~m}$ tall, branchlets hallow, glaucous with latex. Leaves broadly ovate, 15-20 x 10-12 cm, chartaceous, base cordate to truncate, margin entire, apex acuminate. Flowers rose or pink, funnel form in dichotomous, axillary and terminal cymes. Capsules globose or ovoid, seeds hairy.

Remarks: Aggressive colonizer. Common weed of marhsy lands and along the edges of tanks and ditches.

Jatropha gossypiifolia

Family: Euphorbiaceae

Pop. Name: bellyache bush, black physicnut or cotton-leaf physicnut

Nativity: Mexico, South America, Gujarat State (India) and the Caribbean islands

Distribution in Ethiopia: Sherkole \& Kurmuk Districts of BGRS, Northwestern Ethiopia 
Propagation: Seeds, vegetatively stem, root

$\boldsymbol{F l} \& \boldsymbol{F r}$ : July - October

It grows to $2.5-4 \mathrm{~m}(8.2-13.1 \mathrm{ft})$ high. The three lobed leaves are purple and sticky when young and become bright green with age. The small red flowers with yellow centres appear in clusters. These are followed by cherry-sized seed pods that are poisonous.

Remarks: Aggressive colonizer of backyards and degraded ares.

Lantana camara

Family: Verbenaceae

Pop. Name: Lantana, Wild Sage

Nativity: Trop. America (introduced in Ethiopia as ornamental shrub)

Distribution in Ethiopia: Throughout

Propagation: Seeds

$\boldsymbol{F l} \boldsymbol{\&} \boldsymbol{F r}$ : Throughout the year

Citation: Lantana camara L. Sp. P1. 627. 1753; FBI 4: 562. 1885. L. aculeata L. Sp.P1. 627. 1753; Gamble 2: 1087 (761). 1924.

Description: Straggling, armed shrubs, up to $2.5 \mathrm{~m}$ tall. Leaves 2-6 x 1.5-3.5 cm, base cordate, margin crenateserrate, rugose and hispid above, sparsely hispid beneath. Flowers in various colours, pink, white, crimson, orange or rose, in axillary, capitate spikes. Drupes ripe black, 3-4 mm in diam., globose.

Remarks: Aggressive colonizer. Common weed of forests, plantations, habitation, waste lands and scrub lands.

Mimosa pigra

Family: Mimosaceae

Pop. Name: Black Mimosa

Nativity: Trop. North America

Distribution in Ethiopia: Western Ethiopia

Propagation: Seeds

$\boldsymbol{F l} \boldsymbol{\&} \boldsymbol{F r}$ : August - December

Citation: Mimosa pigra L. Sp. Pl. 518. 1753; Verdcourt in Taxon 38:522-523. 1989.

Description: Prickly mimosoid shrub to $3 \mathrm{~m}$ tall; stem has 5 ridges from which spines and bristles arise. Leaves about $20 \mathrm{~cm}$ long and pinnate; 7-16 pairs pinnae, each pinna composed of 25-40 linear pinnules. Petioles and leaves spiny. Leaves are not as sensitive to physical stimulation as Mimosa pudica. Flowers in globose heads. Pods compressed, 5-10 x ca. $2 \mathrm{~cm}$, hispid.

Remarks: Aggressive colonizer. It invades water courses and seasonally flooded wetlands.

Monochoria vaginalis

Family: Pontederiaceae

Nativity: Trop. America

Distribution in Ethiopia: Northwestern regions of Ethiopia (Pawe \& Mandura Districts)

Propagation: Seeds

$\boldsymbol{F l} \& \boldsymbol{F r}$ : August - December

Citation: Monochoria vaginalis (Burm.f.) C. Presl. Rel. Haenk. 1: 128. 1827; FBI 6:363. 1892; Fischer in Gamble 3: 1529(1068). 1928. Pontedera vaginalis Burm.f. Fl. India 80.1768.

Description: Rooted, aquatic herb, $20-70 \mathrm{~cm}$; root stock thick, erect. Leaves ovate, $3-9 \times 1.5-5 \mathrm{~cm}$, thincoriaceous, 9-11 nerved, glarbous, obscurely lobed, cordate, entire, caudate-acuminte. Raceme solitary, terminal to $7 \mathrm{~cm}$, deflexed, 6-10-flowered. Flowers regular, to $2 \mathrm{~cm}$ across. Perianth lobes deep blue. Capsule oblong, $1 x 0.8 \mathrm{~cm}$, glabrous; seeds many, oblong. 10-ribbed.

Remarks: Aggressive colonizer. Common weed of ditches and still waters.

Opuntia stricta

Family: Cactaceae

Pop. Name: Prickly Pear, Snake Hood Fig

Nativity: Trop. America

Distribution in Ethiopia: Northern (Tigray region) \& Northwestern regions of Ethiopia

Propagation: Seeds

$\boldsymbol{F l} \& \boldsymbol{F r}$ : April - December

Citation: Opuntia stricta (Haw.) Haw. Syn. P1. Succ. 191. 1812. var. dillenii (Ker-Gawler) L. Benson. Cact. Succ. J. (Los Angeles) 41: 126. 1969. Cactus strictus Haw. Misc. Nat. 188. 1803. Opuntia dillenii (Ker-Gawler) Haw. Suppl. Pl. Succ. 79. 1819; FBI 2: 657. 1879. Gamble 1: 548(387). 1919.

Description: Shrub to $2.5 \mathrm{~m}$ tall; areoles raised, densely elongate-bristly, glochidiate; Spines 5-7 per areole, 0.7$4.5 \mathrm{~cm}$, yellow. Leaves deciduous. Flowers to $5 \mathrm{~cm}$ across. Perianth yellow. Berry obovoid, purple when ripe; seeds many.

Remarks: Aggressive colonizer. Occasional in thorny scrub and degraded lands. 
Parthenium hysterophorus

Family: Asteraceae

Pop. Name: Congress grass, Parthenium

Nativity: Trop. North America

Distribution in Ethiopia: Throughout

Propagation: Seeds

$\boldsymbol{F l} \& \boldsymbol{F r}:$ July - February

Citation: Parthenium hysterophorus L. Sp. P1. 988. 1753. Pullaiah \& Moulali, Fl. Andhra Pradesh 2: 533. 1997. Description: Annual, erect herbs to $1.5 \mathrm{~m}$ tall; branches angular, grooved, hairy. Leaves alternate, pinnatifid, 2$15 \times$ 0.5-7 cm, pinnules opposite, oblong-lanceolate, base decurrent, apex acute. Heads white, bisexual, in terminal panicles about $20 \mathrm{~cm}$ long, heterogamous, female floret ligulate, anthers translucent. Achenes obovoid, flattened, dorsally compressed.

Remarks: Aggressive colonizer. Common weed of cultivated fields, forests, overgrazed pastures, waste lands and gardens.

Senna alata

Family: Caesalpiniaceae

Pop. Name: Ringworm Cassia, Roman Candle

Nativity: West Indies

Distribution in Ethiopia: Northwestern Ethiopia (Guba, Sherkole, Menge \& Kurmuk Districts of BGRS)

Propagation: Seeds

$\boldsymbol{F l} \& \boldsymbol{F r}$ : May - December

Citation: Cassia alata L. Sp. Pl. 378. 1753; FBI 2: 264. 1878; Gamble 1: 404(286). 1919.

Description: Shrubs up to $2 \mathrm{~m}$ tall. Leaves $30-50 \mathrm{~cm}$ long, leaflets $8-14$ pairs, oblong, $5-12 \times 2-8 \mathrm{~cm}$, inequilateral, thin-coriaceous, glabrous, broadly rounded, oblique at base, margin entire, apex obtuse, apiculate, rachis winged on each side of the face. Flowers yellow in terminal dense racemes, peduncle up to $12 \mathrm{~cm}$ long, bract spathaceous enclosing bud. Pod oblong, thin, straight, $15 \times 1.5 \mathrm{~cm}$, margin with 2 longitudinal wings.

Remarks: Introduced as an ornamental. Occasionally found in moist places and near by forests.

\section{Senna obtusifolia}

Family: Caesalpiniaceae

Pop. Name: Sickle Senna

Nativity: Trop. America

Distribution in Ethiopia: Throughout Lowland areas of Northwestern Ethiopia

Propagation: Seeds

$\boldsymbol{F l} \boldsymbol{\&} \boldsymbol{F r}$ : August - December

Citation: Cassia obtusifolia L. Sp. Pl. 377. 1753; Raju \& Rao in J. Econ. Tax. Bot. 8: 485. 1986. C. tora sensu Baker in FBI 2: 263. 1878, p.p. C. tora L. var. obtusifolia Haines 2: 304.1922.

Description: An annual herb to $1 \mathrm{~m}$ tall. Leaflets 3-5 pairs, 1.5-4 x 1-2.8 cm, obovate-oblong; conical gland between lowest pair of leaflets. Flowers bright yellow in axillary racemes. Three anthers distinctly necked at apex. Pod cylindric, faintly reticulate, beaked, 30-35 seeded.

Remarks: Aggressive colonizer. Abundant along railway tracks, road sides and in degraded forests.

Sida acuta

Family: Malvaceae

Nativity: Trop. America

Distribution in Ethiopia: Throughout

Propagation: Seeds

Fl \& Fr: July - December

Citation: Sida acuta Burm.f. Fl. Indica 147. 1768; Dunn in Gamble 1: 90(64). 1915. S. carpinifolia auct. non. L. Mast. in FBI 1: 323. 1874.

Description: Erect herbs. Leaves oblong-lanceolate or elliptic, 1-8 x 0.4-2 cm, basally 3-5 nerved, serrate, apex acute. Stipules of each pair different. Flowers solitary or 2-5 in clusters. Schizocarp $5 \mathrm{~mm}$, ovoid, acute, wrinkled, with 6-9 mericarps.

Remarks: Aggressive colonizer. Abundant along railway tracks, road sides and in degraded forests.

Striga harmonica

Family: Orobanchaceae

Pop. Name: - Witchweed

Nativity: Africa, Asia, and Australia

Distribution in Ethiopia: Throughout

Propagation: Seeds

Fl \& Fr: September - December 
Description: Striga plants have green opposite leaves, bright irregular flowers with corolla tube slightly bent at the middle. The flowers are pink, red, white or yellow. There is a considerable variation in flower color. The plant is characterized by herbaceous habit, small seeds and parasitism. The seeds of S. hermonthica are extremely small, about $0.2 \mathrm{X} 0.3 \mathrm{~mm}$, weighing about $0.7 \mu \mathrm{g}$. They are generally dispersed by water, wind, cattle, and man .The number of seeds per capsule ranges from $700-1800$ depending on the species. The seeds can remain viable in the field for as long as 14-20 years. The minimal length of the life cycle of the parasite, from germination to seed production comprises an average of 4 months.

\section{Waltheria indica}

Family: Sterculiaceae

Nativity: Trop. America

Distribution in Ethiopia: Throughout

Propagation: Seeds

$\boldsymbol{F l} \& \boldsymbol{F r}$ : August - December

Citation: Waltheria indica L. Sp. P1. 673. 1753; FBI 1: 374. 1874; Dunn in Gamble 1: 111(79). 1915.

Description: Erect herbs or undershrubs. Leaves simple, ovate or elliptic, 2-5.5 x 1-4 cm. thin-coriaceous, leathery, basally 3-or 5-nerved, woolly, obtuse-subcordate, serrate, acute-obtuse. Flowers in axillary clusters; yellow. Capsule obconical, $2 \mathrm{~mm}$, enclosed in calyx, 2-valved; seed 1, obconical, wrinkled, $1.5 \mathrm{~mm}$.

Remarks: Aggressive colonizer. Abundant along railway tracks, road sides and in degraded forests.

\section{Xanthium strumarium}

Family: Asteraceae

Pop. Name: Cocklebur

Nativity: Trop. America

Distribution in Ethiopia: Throughout

Propagation: Seeds

Fl \& Fr: August - March

Citation: Xanthium strumarium L. Sp. Pl. 987. 1753; FBI 3: 303. 1881; Gamble 2: 703 (494). 1921.

Description: Erect herbs, branchlets glandular-pubescent. Leaves 5-12 x 1.5-2.5 cm, ovate-lanceolate to ellipticlanceolate, ca. 15 nerved, base cuneate, with 2 glands, margin crenate-serrate, apex acute; petiole to 2.5 $\mathrm{cm}$ long. Flowers $4 \mathrm{~cm}$ across, homostylous, bracteoles lanceolate, penninerved, pedicel adnate to petiole only at base. Capsule globose, to $8 \mathrm{~mm}$.

Remarks: Aggressive colonizer. Occasional weed of cultivated fields and scrub lands.

\section{References}

1. Abiyot Berhanu, Getachew Tesfaye. The P. juliflora dilemma, impact on dry land biodiversity and some controlling methods. Journal of the Dry Lands. 2006;1(2):158-164.

2. Abiyu Enyew and Nagappan R. Allelopathic effect of Lantana camara L. leaf powder on germination and growth behavior of maize, Zea maysLinn. and wheat, Triticum turgidumLinn. Cultivars. Asian Journal of Agricultural Science. 2015; 7(1):4-10.

3. Adane Kebede Gebeyehu. The distributions of parthenium weed (Parthenium hysterophorus L. Asteraceae) and some of its socio-economic and ecological impacts in the Central Rift Valley, Adami Tulu-Jido Kombolcha Woreda; Addis Ababa University; Ethiopia:Thesis; 2008.

4. Admasu Dubale. Invasive plants and food security: the case of Prosopis juliflorain the Afar Region of Ethiopia, IUCN, 2008;1-12.

5. Almeilla, I.D. \& H. Freitas (2001). The alien and invasive flora of Portugal. Bot. Complutensis 25: 317-327.

6. Anonymous (2005). State of Forest Report: 2003. Forest Survey of India (FSI), Ministry of Environment and Forests, Govt. of India.

7. Baskin, Yvonne. (2002). A Plague of Rats and Rubbervines: The Growing Threat of Species Invasions. Island Press, Washington, D.C.

8. Berkowitz, A.R., C.H. Nilon \& K.S. Hollweg (eds.). (2003). Understanding Urban

9. Brandis. D. (1978). Indian trees. Bishen Singh Mahendra Pal Singh. Dehradun. Calcutta.

10. Champion, H.G. \& S.K. Seth (1968). The Revised Forest types of India. New Delhi.

11. Chatterjee, D. (1940). Studies on the endemic flora of India and Burma. J. Asiat. Soc. Bengal. 5: 19-67.

12. Corlett, R.T. (1988). The naturalized flora of Singapore. Journal of Biogeography 15: 657-663.

13. Cowie, R. (2001). "Does the Public Care about Species Loss? A Glimpse into the Public's Thinking." Conservation Biology in Practice 2(3):28-29.

14. Cox, G.W. (1999). Alien Species in North America and Hawaii: Impacts on Natural Ecosystems. Island Press, Washington, D.C.

15. Cox, G.W. (2004). Alien Species and Evolution: The Evolutionary Ecology of Alien Plants, Animals, Microbes, and Interacting Native Species. Island Press, Washington, D.C. 
16. Cracraft, J. \& T. Francesca (1999). The Living Planet in Crisis. Columbia University Press, New York.

17. Crooks JA. Characterizing ecosystem-level consequences biological invasions: the role of ecosystem engineers. OKIOS. 2002;97(2):153-166.

18. D'Antonio, C.M. \& P.M. Vitousek. (1992). "Biological Invasions by Alien Grasses: the Grass/fire Cycle and Global Change." Annual Review of Ecology and Systematics 23:63- 87.

19. Dar, G.H. (2000). Floristic diversity in India: An overview. pp: 173-196. In: Environment, Biodiversity and Conservation (M.A. Khan \& S. Farooq (eds)). A.P.H. Publishing Corporation, New Delhi.

20. David M Richardson, Pierre Binggeli, Gotz Schroth. Invasive agroforestry trees: problems and solutions. 2003;15:371-396.

21. Drake, J.A., H.A. Mooney, F. di Castri, R. Groves, F. Kruger, M. Rejmanek \& M. Williamson (eds.). (1989). Biological Invasions: A Global Perspective. John Wiley and Sons, New York.

22. EBI (Ethiopian Biodiversity Institute). Ethiopian's fifth national report to the conservation biodiversity. 2014.

23. Ecosystems: A New Frontier for Science and Education. Springer-Verlag, New York.

24. Edwards, S., Mesfin Tadesse \& Hedberg, I. (eds.), 1995. Flora of Ethiopia and Eritrea. Vol. 2,2. Canellaceae to Euphorbiaceae. Addis Ababa, Ethiopia \& Uppsala, Sweden.

25. Edwards, S., Mesfin Tadesse, Sebsebe Demissew \& Hedberg, I. (eds.), 2000. Flora of Ethiopia and Eritrea. Vol. 2,1.

26. Edwards, S., Sebsebe Demissew \& Hedberg, I. (eds.), 1997. Flora of Ethiopia and Eritrea Vol. 6. Hydrocharitaceae to Arecaceae. Addis Ababa, Ethiopia \& Uppsala, Sweden.

27. Elton, Charles S. (2000). The Ecology of Invasions by Animals and Plants. University of Chicago Press, Chicago.

28. Enmoto, T. (1999). Naturalized weeds from foreign countries into Japan. In: Yano, et al. (eds.). Biological invasions of ecosystem by pests and beneficial organisms. National Institute of Agro-Environmental Science, Tsukuba, Japan. pp. 1-14.

29. Esther Mwangi, Brent Swallow. Invasion of Prosopis julifloraand local livelihoods: Case study from the lake Baringo area of Kenya.. World Agroforestry Centre, 2005;3:1-66.

30. Feasibility Study. 2001. Feasibility Study and Environmental Impact Assessment for: Assosa-Guba Road project. NDF Credit No. 207-TD1. November 2001. Carl Bro a/s Transport Department, in association with DANA Consult Plc Engineering Consultants.

31. Flora of Taiwan. Taiwania, 49(1):16-31, 2004.

32. Friis I Demissew S, Breugel PV. Atlas of potential vegetation of Ethiopia. The Royal Danish Academy of Sciences and Letters. Biologiske Skrifter. 2010;58:307.

33. Friis, I. \& Sebsebe Demissew. 2001. Vegetation maps of Ethiopia and Eritrea. A review of the existing maps and the need for a new map for the Flora of Ethiopia and Eritrea. Biol. Skr. 54: 399-439.

34. Friis, I. 1992. Forest and Forest Trees of Northeast Tropical Africa. Their Natural Habitats and Distribution Patterns in Ethiopia, Djibouti and Somalia. Kew Bull., Addit. Ser. 15.

35. Friis, I. 2001. Progress with the botanical exploration of Ethiopia and Eritrea during the last forty years. Systematics and Geography of Plants 71: 165-186.

36. Friis, I., Thulin, M., Adsersen, H. \& Bürger, A.-M. 2005. Patterns of plant diversity and endemism in the Horn of Africa. Biol. Skr. 55: 289-314.

37. Gamble, J.S. \& C.E.C. Fischer (1915-1935). Flora of the Presidency of Madras. London. (rep. ed. 1957: BSI, Calcutta).

38. Getachew Gebru Tegegn. Experiences on Prosopis juliflora management:The case of Afar Region, Ethiopia: Farm Africa; 2008. p. 1-35.

39. Gilbert, M.G. 2002. Notes on the Ceropegiae (Asclepiadaceae) of Ethiopia. Nord. J. Bot. 22: 205-210.

40. Global Environment Facility (GEF). Removing Barriers to Invasive Plant Management in Africa. Country Report on National Stakeholders Workshop on Invasive Alien Species. August 17-18, 2002. Addis Ababa, Ethiopia. 21

41. Gnanavel L. Parthenium hysterophorus L: a major threat to natural and agro-ecosystems in India. Science International, 2013;1(5):124-131.

42. Greg Masters and Lindsey Norgrove. Climate change and invasive alien species, CABI Position Paper. 2010;1-30.

43. Hajra, P. K. \& B.K. Das, (1982). Vegetation of Gangtok with special reference to alien plants. Indian For. 107: 554-566.

44. Hajra, P.K. \& V. Mudgal (1997). Plant diversity hotspots in India - An overview. BSI. India.

45. Heather Charles, Jeffrey S Dukes. Impacts of invasive species on ecosystem services. Ecological Studies, 2007;193:9-15.

46. Hedberg, I. \& Edwards, S. (eds.), 1989. Flora of Ethiopia. Vol. 3. Pittosporaceae to Araliaceae. Addis 
Ababa and Asmara, Ethiopia \& Uppsala, Sweden.

47. Hedberg, I. \& Edwards, S. (eds.), 1995. Flora of Ethiopia and Eritrea. Vol. 7. Poaceae. By Sylvia Phillips. Addis Ababa, Ethiopia \& Uppsala, Sweden.

48. Henry, A.N., G.R. Kumari \& V. Chitra. (1989). Flora of Tamil Nadu, India. Series 1: Analysis. Vol. 2. BSI. Coimbatore.

49. Heywood, V. (1989). "Patterns, Extents, and Modes of Invasions by Terrestrial Plants." Pages 31-60 in J. Drake et al. (eds.), Biological Invasions: A Global Perspective, Wiley, NY.

50. Hooker, J.D. (1904). A sketch of Flora of British India. London.

51. Huxel, G.R. (1999). "Rapid Displacement of Native Species by Invasive Species: Effects of Hybridization." Biological Conservation 89:143-152.

52. IBC (Institute of Biodiversity Conservation). National biodiversity strategy and action plan. Retrieved from http://www.ibc.gov.et/publications/all-publications.2005. 24

53. Jadhav, S.N., D.K. Ved, U. Ghate, K.N. Reddy \& C.S. Reddy (2001). Proceedings of the Conservation Assessment and Management Planning Workshop: Medicinal Plants of Andhra Pradesh. Environment Protection Training \& Research Institute. Hyderabad.

54. Jama B and Zeila A. Agro forestry in the drylands of eastern Africa: a call to action. ICRAF, World Agroforestry Centre. 2005:1-29.

55. Jenkins, P.T. (1999). A global strategy for dealing with alien invasive species. Invasive species and Biodiversity management (ed. O.T. Sandlund, P.J. Schei and A. Viken), Vol. 24. 229-235. Kluwer Academic Publishers, London.

56. John F Obiri. Invasive plant species and their disaster-effects in dry tropical forests and rangelands of Kenya and Tanzania. Journal of Disaster Risk Studies. 2011;3(2).

57. Jyothi M, Vamsi J, Satish S. Lantana camara L: a review, International Journal of Phytotherapy. 2012;2(2):66-73.

58. Karthikeyan, S. (1999). Flowering plant diversity of India: Monocotyledons. pp: 83-95. In: Biodiversity, Taxonomy and Ecology (R.K. Tandon \& Prithipalsingh (eds)). Scientific Publishers (India).

59. Kassahun Zewide. Host-specificity sytudy on the leaf feeding beetlle, of Zygograma bicolorata (Coleoptera: Chrysomelidae) for the control of Parthenium hysterophorus in Ethiopia.International Workshop on Parthenim Weed in Ethiopia; 2014; Ethiopia Addis Ababa; 2014.

60. Kueffer C, Vos P Lavergne C, Mauremootoo J. Case Studies on the Status of Invasive Woody Plant Species in the Western Indian Ocean, Synthesis. Forestry Department, Food and Agriculture Organization. 2004.

61. Londsdale, W.M. (1999). "Global Patterns of Plant Invasions and the Concept of Invasibility." Ecology 80:1522-1536.

62. Lowe S, Browne M, Boudjelas S, De Poorter M. 100 of the world's worst invasive alien species a selection from the global, invasive species database. ISSG. 2000;6:1-11.

63. Magnoliaceae to Flacourtiaceae. Addis Ababa, Ethiopia \& Uppsala, Sweden.

64. Mahadevappa, M. \& Ramaiah, H. (1990). Pattern of replacement of Parthenium hysterophorus plants by Cassia sericea in waste lands. Indian Journal of Weed Science 20:83-85.

65. Maheswari, J.K. \& S.R. Paul (1975). The alien flora of Ranchi. J. Bombay Nat. Hist. Soc. 72(1): 158-188. 1975.

66. Manilal, K.S. \& K. Raveendrakumar (1998). Additions to the Flora of Kerala since Gamble (1935). Rheedea 8: 179-241.

67. Matthew, K.M. (1969). Alien flora of Kodaikanal and Palni hills. Rec. Bot. Surv. India. 20(1): 1-241.

68. Mc Neely JA, Mooney HA, Neville LE, et al. A Global Strategy on Invasive Alien Species.IUCN Gland, Switzerland, and Cambridge, UK. 2001; p.3

69. McNeely JA, H.A. Mooney, L.E. Neville, P. Schei \& J.K. Waage (2001). A Global Strategy on Invasive Alien Species. IUCN Gland, Switzerland, and Cambridge, U.K., in collaboration with the Global Invasive Species Programme.

70. Meher-Homji, V.M. (2001). Bioclimatology and Plant Geography of Peninsular India. Scientific Publishers, Jodhpur, India.

71. Mersie. Management of the weed Parthenium (Parthenium hysterophorus L.) in Eastern and Southern Africa using integrated cultural and biological measures.International Workshop on Parthenim Weed; 2014; Ethiopia; Addis Ababa, 2014.

72. Meyer, J.Y. (2000). Preliminary review of the invasive plants in the Pacific islands. In: Sherley, G. (ed.), Invasive Species in the Pacific: A Technical Review and Draft Regional Strategy. South Pacific Regional Environmental Programme, Samoa. pp. 85- 114.

73. Michelle C Mack, Carla MD Antonio. Impacts of biological invasions on disturbance regimes. Trends Ecol Evol. 1998;13(5):195-198.

74. Mishra, K.K. (1995). A census of the alien species of Alternanthera Forssk. (Amaranthaceae) in Bihar. J. 
Econ. Tax. Bot. 19: 613-619.

75. Mooney, H.A. \& J.A. Drake. (1987). "The Ecology of Biological Invasions." Environment 29(5):12.

76. Mooney, H.A. \& R.J. Hobbs (eds.). (2000). Invasive Species in a Changing World. Island Press, Washington, D.C.

77. Mooney, H.A. (1999). A global strategy for dealing with alien invasive species. Invasive species and Biodiversity management (ed. O.T. Sandlund, P.J. Schei and A. Viken), Vol. 24. Kluwer Academic Publishers, London.

78. Moyo HPM, Fatunbi AO. Utilitarian perspective of the invasion of some South African biomes by Acacia mearnsii. Global Journal of Environmental Research. 2010;4(1):6-17.

79. Mudgal, V. \& P.K. Hajra (1999). Floristic Diversity and Conservation Strategies in India (Ed.) Vol. II. BSI, Calcutta.

80. Murthy, E.N., V.S. Raju \& C.S. Reddy (2007). Occurrence of alien Hyptis suaveolens. Curr. Sci. 93(9): 1203.

81. Nair, N.C. \& A.N. Henry. (1983). Flora of Tamil Nadu, India. Series 1: Analysis. Vol. 1. BSI. Coimbatore.

82. Nayar, M.P. \& A.R.K. Sastry (1987). Red Data Book of Indian Plants. Vol. 1. BSI,

83. Nayar, M.P. (1977). Changing patterns of the Indian Flora. Bull. Bot. Surv. India 19: 145- 155.

84. Nayar, M.P. (1989). In Situ Conservation of Wild flora resources. Bull. Bot. Surv. India 29: 319-333.

85. Negi, P.S. \& P.K. Hajra (2007). Alien flora of Doon valley, North west Himalaya. Curr. Sci. 92(7): 968-978.

86. Ngweno CC, Mwasi MS, Kairu KJ. Distribution, density and impact of invasive plants in Lake Nakuru National Park, Kenya. Journal of Ecology. 2009;48(4):905-913.

87. Pandey, R.P. \& P.J. Parmar (1994). The alien flora of Rajasthan. J. Econ. Tax. Bot. 18(1):

88. Pierre Binggeli, John B Hall, John R Healey. An overview of invasive woody plants in the tropics. School of Agricultural and Forest Sciences. 1998;13.

89. Pullaiah, T. \& D. Alimoulali (1997). Flora of Andhra Pradesh. Vol. II. Scientific Publishers, Jodhpur.

90. Pullaiah, T. \& E. Chennaiah (1997). Flora of Andhra Pradesh. Vol. I. Scientific Publishers, Jodhpur.

91. Pullaiah, T. (1997). Flora of Andhra Pradesh. Vol. III. Scientific Publishers, Jodhpur.

92. Pyšek, P., J. Sádlo \& B. Mandák (2002). Catalogue of alien plants of the Czech Republic. Preslia. 74:97186.

93. Raju, V.S. \& N. Rama Rao (1986). On the identity and distribution of Cassia obtusifolia in southern India. J. Econ. Tax. Bot. 8: 485-486.

94. Raju, V.S. \& P.N. Rao (1976). China Dodder (Cuscuta chinensis Lamk.) on cowpea - A new record. Curr. Sci. $45: 839,840$.

95. Raju, V.S. (1987). Alligator weed in Andhra Pradesh. Indian Bot. Reporter 5: 207, 208.

96. Randall, John M. \& Jane Marinelli (eds.). (1997). Invasive Plants: Weeds of the Global Garden. Brooklyn Botanic Garden, Brooklyn, New York.

97. Rao, E.S., D.S. Kumari \& V.S. Raju (1998). Allelopathic effect of Hyptis suaveolens (L.) Poit. on seedling growth of four crops and a weed. In : I.A. Khan (Ed.), Frontiers in Plant Science. pp. 73-85, Hyderabad.

98. Reddy, C.S. \& K.N. Reddy (2004). Cassia rotundifolia Pers. (Caesalpiniaceae): A new record for India. J. Econ. Tax. Bot. 28: 73-74.

99. Reddy, C.S. \& V.S. Raju (1999). Gnaphalium coarctatum Willd. (Asteraceae): A new record for southern India. J. Econ. Tax. Bot. 23: 687-688.

100. Reddy, C.S. \& V.S. Raju (2002). Additions to the weed flora of Andhra Pradesh, India. J. Econ. Taxon. Bot. 26: $195-198$.

101.Reddy, C.S., A.H. Naqvi \& V.S. Raju (2000). Rorippa dubia (Pers.) Hara (Brassicaceae): A new record for southern India. J. Econ. Tax. Bot. 24: 287-288.

102.Reddy, C.S., K.N. Reddy \& V.S. Raju (2000). Cardamine trichocarpa Hochst.ex Rich. and Cleome rutidosperma DC. - As alien weeds in Andhra Pradesh, India. J. Econ. Tax. Bot. 24: 291-292.

103.Reddy, C.S., K.N. Reddy, M.R. Bhanja \& V.S. Raju (1999). On the identity of Physalis minima L. (Solanaceae) in southern India. J. Econ. Tax. Bot. 23: 709-710.

104.Reddy, C.S., M.R. Bhanja \& V.S. Raju (1999). Nicotiana plumbaginifolia Viv. And Youngia japonica (L.) DC.- New records for the flora of Andhra Pradesh, India. J. Econ. Tax. Bot. 23: 685-686.

105.Reddy, C.S., M.R. Bhanja \& V.S. Raju (2000). Cassia uniflora Miller: A new record for Andhra Pradesh, India. Indian J. Forestry 23 (3): 324-325.

106. Reddy, M.H. \& R.R.V. Raju (1997). Taxonomic study of the family Amaranthaceae in South India. J. Econ. Tax. Bot. 21: 577-586.

107. Rezene Fessehaie, Taye Tessema.Alien plant species invasions in Ethiopia: challenges and responses. International Workshop on Parthenium Weed in Ethiopia, Addis Ababa.2014.

108. Rezene Fessehaie. Status of water hyacinth (Eichhornia crassipes) in Ethiopia: challenges and response. Inc: Proceedings of the second national workshop on challenges and opportunities of water resources 
management in Tana Basin, Upper Blue Nile Basin, Ethiopia, March 26 - 27, 2012. Blue Nile Water Institute-Bahir Dar University (BNWI-BDU), pp. 159-166, Bahir Dar, Ethiopia.

109. Richard Beilfuss. Adaptive management of the invasive shrub Mimosa pigra at Gorongosa National Park. Department of Scientific Services. 2007;1-19.

110.Saxena, H. O. \& M. Brahmam (1996). The Flora of Orissa, Vol I-IV, Orissa Forest Development Corporation. Bhubaneswar.

111. Saxena, K.G. 1991. Biological invasion in the Indian sub-continent: Review of invasion by plants. In Ecology of Biological Invasion in the Tropics, 1991, pp. 53-73.

112. Sebua S Semenya, Milingoni P Tshisikhawe, Martin T Potgieter. Invasive alien plant species: A case study of their use in the Thulamela Local Municipality, Limpopo Province, South Africa.Scientific Research and Essay. 2012;7(27):2363-2369.

113. Sharma, B.D. \& D.S. Pandey (1984). Alien flora of Allahabad. BSI, Calcutta.

114. Shetie Gatew. The Ecological Distribution and Socio-Economic impacts of Prosopis juliflora (Sw.) DC. in the Amibara Woreda, Afar National Regional State. 2008.

115. Shilashi Badasa, Tesfahun Bufebo, Tessema Derbe, et al. Physico-chemical analysis of essential oil of Lantana camara L.leaf. World Journal of Pharmacy and Pharmaceutical Sciences. 2013;3(10):1349-1357.

116. Shine C, Kettunen M, Ten Brink P. Technical support to EU strategy on invasive species (IAS)Recommendations on policy options to control the negative impacts of IAS on biodiversity in Europe and the EU. Final report for the European Commission; 2009; Brussels, Belgium: 2010.

117. Sintu Alemayehu. Host-range study on the stem-boring weevil (Listronotus setosipennis (Coleoptera: Curculionidae) for the control of Parthenium hysterophorus in Ethiopia. Inc: International Workshop on Parthenium Weed in Ethiopia; 2014; Ethiopia; Addis Ababa, 2014.

118. Sonya Afrin, Subarna Sharmin, Qazi Azizul Mowla, editors. The environmental impact of alien invasive plant species in Bangladesh. Proceedings of International Conference on Environmental Aspects of Bangladesh; 2010 Sept Japan. ICEAB10; 2010.

119. Talemos Seta, Abreham Assefa, Fisseha Mesfin, et al. Distribution status and the impact of parthenium weed (Parthenium hysterophorus L.) at Gedeo Zone, Southern Ethiopia. African Journal of Agricultural Research, 2013;8(4):386-397.

120. Tamado Tana Ohlander L, Milberg P. Interference by the weed Parthenium hysterophorus L. with grain sorghum: influence of weed density and duration of competition. International Journal of Pest Management. 2002;48(3):183-188.

121. Tamando Tana and Milberg P. Weed flora in arable fields of eastern Ethiopia with emphasis on the occurrence of Parthenium hysterophorus L. Weed Research. 2010;40(6):507-521.

122. Temitope Israel Borokini. Invasive alien plant species in Nigeria and their effects on biodiversity conservation. Journal of Tropical Conservation Science, 2011;4(1):103-110.

123. Tesfaye Awas (2007) Plants diversity in Western Ethiopia: ecology, ethnobotany and conservation. $\mathrm{PhD}$ dissertation, University of Oslo, Norway, Europe.

124.Turrill, W.B. (1964). Plant taxonomy, Phytogeography and Plant ecology. In: Vistas in Botany, Vol. IV. Pergamon Press, London.

125.UNEP (United Nations and Environmental Programme). Water hyacinth - Can its aggressive invasion be controlled?Global environmental alert service (GEAS). Taking the pulse of the planet. 2013;1-17.

126. Wakjira Mulatu, Berecha Gezahegn, Tulu Solomon. Allelopathic effects of an invasive alien weed Parthenium hysterophorus L. compost on lettuce germination and growth. African Journal of Agricultural Research. 2009;4(11):1325-1330.

127. World Conservation Monitoring Centre (1992). Global biodiversity: Status of the Earths Living Resources. Chapman \& Hall. London.

128. Wu, Shan-Huah, Chang-Fu Hsieh \& M. Rejmánek (2004). Catalogue of the Naturalized

129. Yibekal Abebe. Ecological and economic dimensions of the paradoxical invasive species- Prosopis julifloraand policy challenges in Ethiopia. Journal of Economics and Sustainable Development. 2012;3(8):2222-2855. 